\title{
Peningkatan Kemandirian Peternak Desa Klabang Melalui Village Breeeding Center dan Penerapan Teknologi Pengolahan Pakan Lokal
}

\author{
Listya Purnamasari $^{\left.{ }^{*}\right)}$, Melinda Erdya Krismaputri ${ }^{1)}$, Himmatul Khasanah ${ }^{1)}$, Nur Widodo ${ }^{1)}$ \\ ${ }^{1)}$ Program Studi Peternakan, Fakultas Pertanian, Universitas Jember \\ * Email : listyap.faperta@unej.ac.id
}

\begin{abstract}
Abstrak
Kegiatan program pengabdian desa binaan ini dilakukan di Desa Klabang, Kecamatan Tegalampel, Kabupaten Bondowoso. Kegiatan yang dilakukan yaitu peningkatan kemandirian peternak desa Klabang melalui Village Breeeding Center dan penerapan teknologi pengolahan pakan ternak asal sumberdaya lokal. Manajemen budidaya yang tepat dan ketersediaan pakan berkualitas secara mandiri diharapkan mampu meningkatkan reproduksi dalam hal bibit ternak dan produktivitas ternak. Mitra dalam kegiatan program pengabdian desa binaan ini yaitu masyarakat Desa Klabang, Kecamatan Tegalampel, Kabupaten Bondowoso. Tujuan pengabdian ini yaitu meningkatkan kemandirian peternak dengan pemberdayaan sumber daya manusia yang terampil dalam manajemen budidaya dan pengolahan pakan ternak. Metode yang digunakan dalam program ini yaitu, penyuluhan dan pelatihan manajemen pemeliharaan ternak serta recording ternak dan pemanfaatan limbah pertanian sebagai pakan ternak, penyuluhan dan pelatihan formulasi pakan dan pembuatan pakan fermentasi, pendampingan, monitoring dan evaluasi. Hasil dari program pengabdian kepada masyarakat ini adalah kelompok tani-ternak Desa Klabang Kabupaten Bondowoso mampu mengolah limbah pertanian menjadi pakan ruminansia kaya nutrisi. Buku panduan dan video tahapan pembuatan pakan dapat digunakan oleh masyarakat dengan baik sehingga kelompok tani-ternak dapat mengolah limbah menjadi pakan secara mandiri. Kelompok tani ternak desa Klabang selaku mitra program pengabdian ini dapat melaksanakan dan menerapkan teknologi yang telah diberikan dan berusaha untuk selalu kontinu dalam pembuatan pakan serta pengembangan produk silase sebagai upaya meningkatkan kesejahteraan dan keberlanjutan program.
\end{abstract}

Kata kunci: limbah pertanian, vilage breeding center, Desa Klabang

\section{Pendahuluan}

Kabupaten Bondowoso memiliki beberapa daerah sentra pengembangan komoditas pertanian dan peternakan. Sektor pertanian dan peternakan merupakan salah satu sumber pendapatan utama masyarakat petani/peternak di desa Klabang Kecamatan Tegalampel, Kabupaten Bondowoso dengan komoditas utama jagung, padi dan palawija dengan luas wilayah persawahan sebesar 17 hektar. Selain bertani, masyarakat desa ini juga membudidayakan ternak sapi sebagai tambahan penghasilan dan tabungan masa depan. Disekitar lahan pertanian diselingi tanaman pakan ternak seperti rumput gajah untuk mempermudah peternak mencari pakan dan memanfaatkan keterbatasan lahan. 


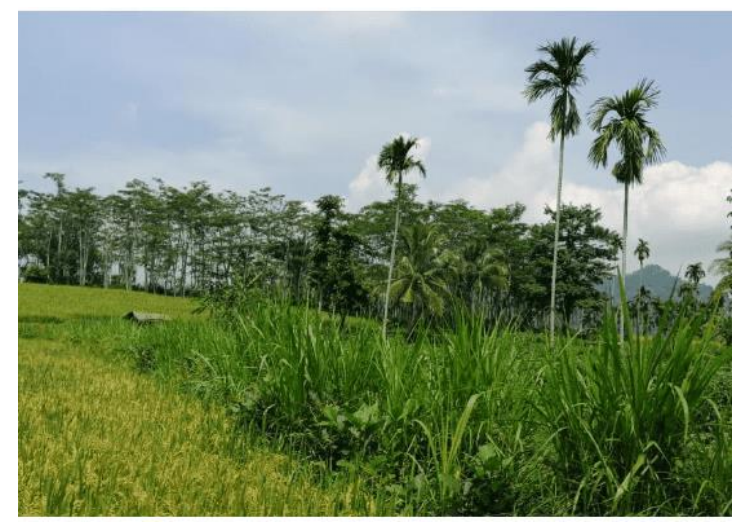

Gambar 1. Kondisi wilayah desa klabang

Kabupaten jember Bondowoso juga merupakan salah satu kabupaten di jawa timur yang memiliki potensi dalam penggembangan komoditas sapi utamanya breeding sapi. Desa Klabang merupakan salah satu sentra ternak sapi dengan jumlah sapi yang dipelihara yaitu 2-3 ekor setiap kepala keluarga dengan jumlah kepala keluarga sebanyak 900 (KK).
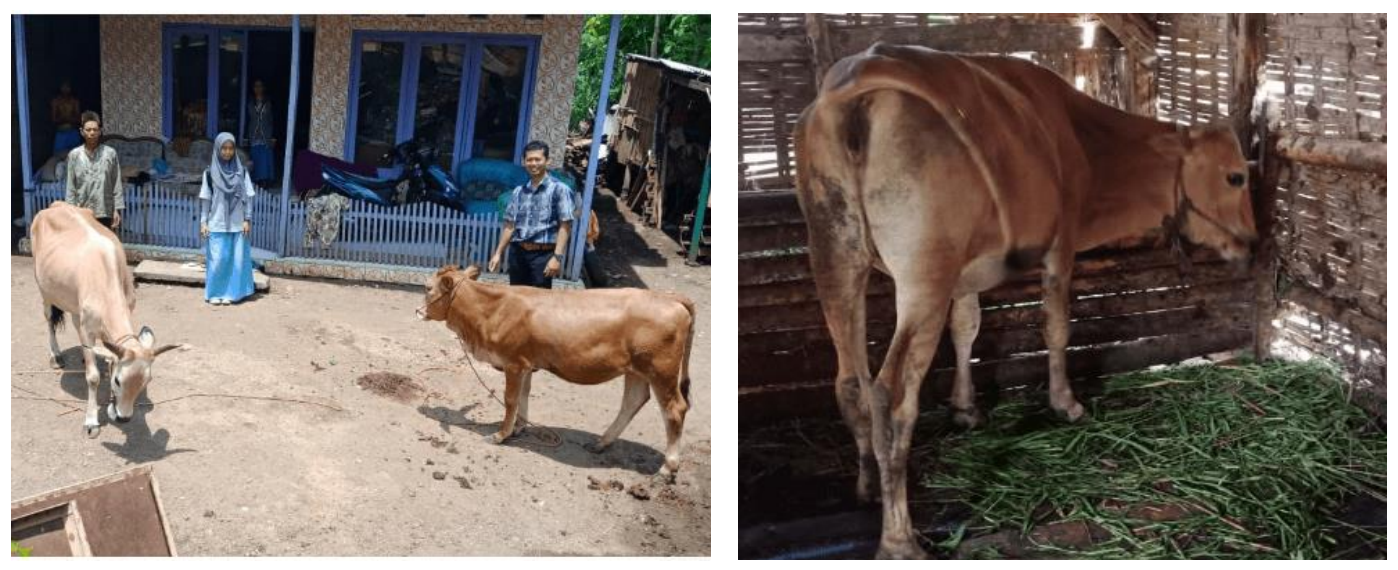

Gambar 2. Peternakan rakyat sapi potong

Program KKN Tematik yang dilaksanakan di desa ini bertemakan TIK telah terlaksana dengan baik. Namun, fakta di lapangan menunjukkan bahwa masyarakat masih membutuhkan dukungan, bimbingan dan pelatihan mengenai kemandirian usaha utamanya dalam bidang peternakan dikarenakan melimpahnya potensi desa yang dapat dimaksimalkan untuk kemandirian petani dan peternak. Lahan pertanian dan perkebunan Desa Klabang yang luas memiliki potensi sebagai bahan baku pakan lokal serta limbah pertanian yang masih dapat dimanfaatkan sebagai pakan ternak sapi berkualitas. Pakan ternak sapi yang diberikan masyarakat di Desa Klabang yaitu rumput lapangan sangat melimmpah karena kondisi daerah yang merupakan sumber air sehingga ketersediaan air selalu ada walau musim kemarau serta limbah pertanian yang melimpah tentu perlu adanya teknologi untuk pengawetan dan peningkatan nilai nutrien. 

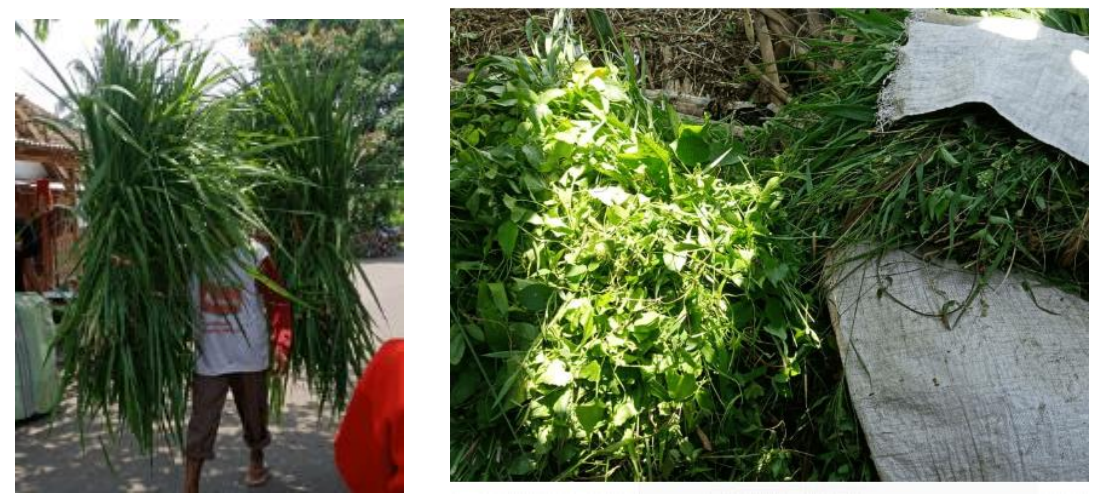

Gambar 3. Ketersediaan hijauan yang melimpah

Pemeliharaan ternak sapi di desa Klabang masih sangat tradisional padahal potensi desa sangat mendukung diterapkannya manajemen budidaya tang tepat yang nantinya dapat menjadi desa sentra breeding atau pembibitan ternak. Strategi yang harus ditempuh untuk menanggulangi kendala yang dihadapi oleh masyarakat peternak di Desa Klabang Kecamatan Tegalampel, Bondowoso tersebut adalah pendampingan dan pelatihan manajemen budidaya ternak khususnya ternak breeding/pembibitan serta pengolahan pakan berkualitas dengan peningkatan nutrien, nilai guna limbah dan menghilangkan kandungan antrinutrisi. Penerapan IPTEKS yang dimaksud dalam kegiatan ini yaitu transfer teknologi budidaya ternak breeding melalui penerapan teknologi tepat guna dengan pelatihan dan demonstrasi tentang manajemen budidaya ternak pembibitan, pelatihan, percontohan terstruktur untuk pembuatan pembuatan pakan ternak fermentasi asal limbah pertanian yaitu silase dan konsentrat fermentasi.

Permasalahan-permasalahan yang sering dihadapi desa Klabang Kecamatan Tegalampel, Kabupaten Bondowoso yaitu pengetahuan peternak mengenai budidaya ternak breeding/pembibitan dan kualitas/kuantitas pakan ternak masih tergolong rendah. Selain itu limbah pertanian seperti limbah tebon jagung, kulit jagung, janggel jagung dan jerami padi yang melimpah dan belum termanfaatkan dengan baik sehingga mencemari lingkungan. Limbah pertanian memiliki potensi yang cukup tinggi untuk digunakan sebagai bahan baku pakan ternak. Keterbatasan pengetahuan dalam budidaya dan pengolahan limbah pertanian menyebabkan masyarakat kurang mengoptimalkan potensi yang ada dengan maksimal.

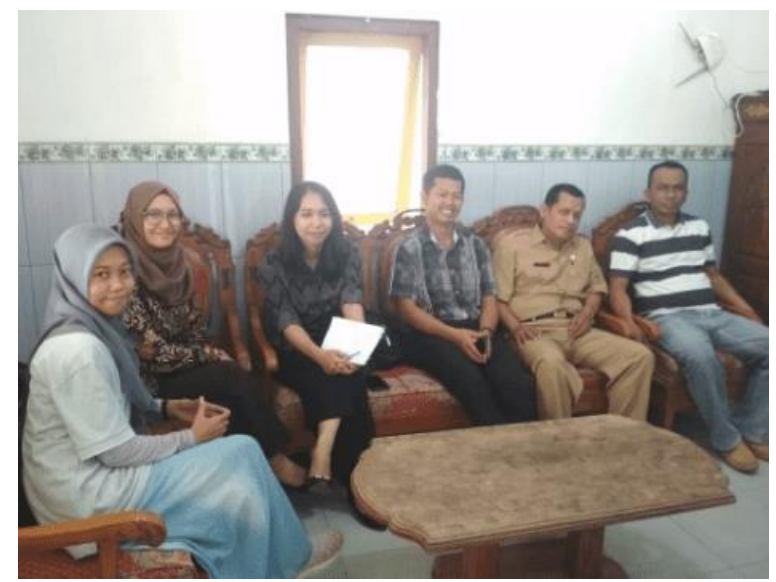

Gambar 4. Diskusi bersama Kepala Desa Klabang 


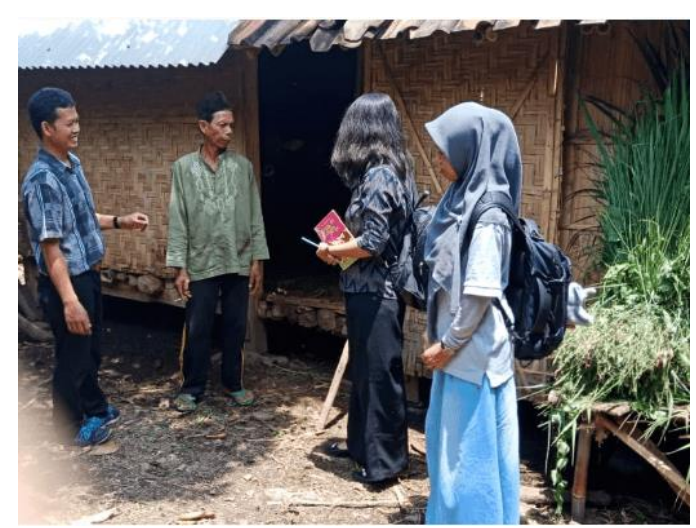

Gambar 5. Diskusi bersama salah satu peternak Desa Klabang

\section{Tujuan Pelaksanaan}

Tujuan pengabdian ini yaitu meningkatkan kemandirian peternak dengan pemberdayaan sumber daya manusia yang terampil dalam manajemen budidaya dan pengolahan pakan ternak.

\section{Metode Pelaksanaan}

Pembinaan yang dilakukan terhadap mitra meliputi beberapa hal yaitu: Upaya yang dilakukan untuk untuk mentransfer teknologi pengolahan pakan ternak ini di desa Klabang yaitu (1) penerapan teknologi tepat guna dengan pelatihan dan demonstrasi tentang manajemen budidaya ternak pembibitan. Kegiatan ini memberikan pengetahuan dan wawasan tentang manajemen budidaya ternak, manajemen perkandangan, rekording dan manajemen reproduksi ternak (2) Fokus materi pelatihan pemanfaatan limbah pertanian dan pengenalan bahan baku lokal yang dapat digunakan sebagai pakan ternak kegiatan ini mengedukasi peternak dalam pemberian dan pengolahan bahan pakan asal sumberdaya lokal dan meningkatkan nutrien yang dibutuhkan oleh ternak baik dalam fase anakan, buntuk menyusui dan dewasa serta pemanfaatan limbah pertanian melimpah. Ketersedian limbah pertanian memiliki nutrisi yang cukup untuk dijadikan pakan (3) Melakukan pelatihan, percontohan terstruktur untuk pembuatan pembuatan pakan ternak fermentasi asal limbah pertanian yaitu silase dan konsentrat fermentasi. Teknologi fermentasi dapat dimanfaatkan untuk mengolah limbah pertanian yang kemudian digunakan sebagai pakan ternak yang kaya akan nutrisi. (4) Melakukan pelatihan pemberian tanda pada ternak dan aplikasi pakan tambahan konsentrat fermentasi ke ternak sapi. Kegiatan ini dilakukan dengan melatih pemberian tanda ternak, pengukuran body condition score dan aplikasi pemberian pakan (5) Melakukan monitoring dan evaluasi manajemen bubidaya dan aplikasi pakan hijauan, silase dan konsentrat fermentasi terhadap efisiensi pakan ternak dan performa produksi ternak. Kegiatan pengabdian ini diharapkan dapat meningkatkan keterampilan peternak desa Klabang, kecamatan Tegalampel, Kabupaten Bondowoso dalam budidaya pembibitan ternak, meningkatkan nilai guna limbah pertanian dan pemanfaatan bahan baku lokal serta pengolahan limbah peternakan di desa Klabang sehingga dapat terintegrasi dengan baik dan menjadi village breeding center.

\section{Hasil dan Pembahasan}

Permasalahan yang dihadapi pada peternak di desa Klabang, kecamatan Tegalampel, Bondowoso yaitu keterampilan manajemen pemeliharaan utamanya ternak indukan (sebagai penghasil bibit) dan pengolahan pakan ternak asal limbah-limbah pertanian oleh masyarakat yang masih rendah serta ketersediaan pakan yang musiman yang terbatas. Manajemen pemeliharaan masih dilakukan sangat tradisional tanpa memperhatikan jarak kawin dan jarak beranak. Faktor pakan seperti hijauan akan melimpah pada saat musim penghujan. Keterbatasan pengetahuan peternak dalam pemanfaatan limbah pertanian juga menjadikan salah satu kendala rendahnya produktivitas ternak di Desa Klabang. Program pengabdian desa binaan melatih para petani dan peternak dalam kemampuan memanajemen pemeliharaan ternak dan pengoptimalan nilai nutrien yang diberikan pada ternak serta pengawetan bahan pakan asal limbah dengan teknologi fermentasi. Kegiatan yang dilakukan dalam program 
pengabdian pemula ini yaitu sosialisasi, pelatihan, monitoring dan evaluasi program. Kegiatan pengabdian desa binaan di desa Klabang kecamatan Tegalampel telah terlaksana sampai tahap pelatihan pembuatan pakan ternak bernutrisi tinggi. Petani peternak sejumlah 30 orang sangat antusias mengikuti kegiatan-kegiatan yang dilakukan dalam pengabdian ini.

\section{Sosialisasi kegiatan dengan pengenalan Village Breeding Center}

Kegiatan awal yang di lakukan dalam memulai program pegabdian yaitu sosialisasi kegiatan dengan pengenalan Village Breeding Center kepada para perangkat desa utamanya kemudian dilanjutkan kepada para peternak. Harapan program ini yaitu desa Klabang menjadi desa dengan basis bibit yang unggul sehingga para pengembang/pengusaha penggemukan bisa mencari bibit-bibit berkualitas di desa ini. Kegiatan sosialisasi diawali dengan pencarian masyarakat petani dan peternak yang berminat mengikuti pelatihan dan sosialisasi village breeding center. Sejumlah 30 orang petanipeternak berminat untuk mengikuti kegiatan sosialisasi dan pelatihan yang dilakukan pada bulan juli agustus 2019.

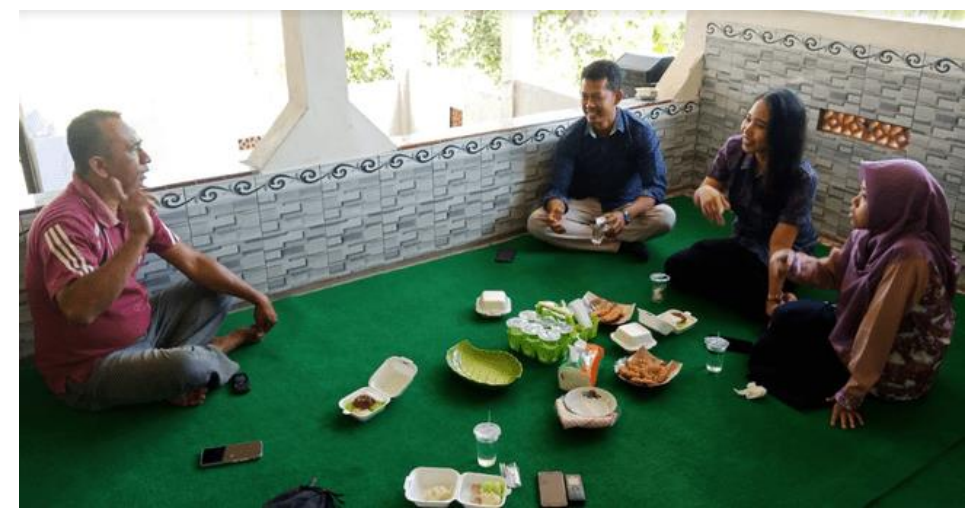

Gambar 6. Permohonan izin kepada kepala desa Klabang, kecamatan tegalampel, Bondowoso

\section{Penyuluhan manajemen breeding ternak untuk kemandirian peternak dengan penerapan Village Breeding Center}

Kegiatan penyuluhan dilakukan pada akhir bulan Juli 2019 dengan tema pertama yaitu manajemen breeding ternak. Peternak di desa Klabang memelihara banyak yang memelihara sapi. Hampir setiap satu kepala keluarga mempunyai 1-3 ekor ternak sapi. Sebagian besar peternak memelihara ternak berdasarkan pengalaman tanpa dilandasi ilmu pengetahuan dan keterampilan khusus. Sehingga mereka kurang mengenal tiga faktor dasar dalam pemeliharaan yaitu breeding, feeding dan management. Dalam mencapai target produktivitas yang baik, ketiga faktor tersebut harus dipahami dan dilaksanakan dengan baik. Breeding sapi sangat dipegaruhi oleh siklus reproduksi. Pada sapi betina, Siklus ini dimulai dengan pubertas atau dewasa kelamin yang ditandai dengan berfungsinya organ-organ kelamin betina. Kemudian musim kawin yang ditandai dengan siklus birahi, kopulasi, adanya kelahiran setelah kebuntingan dan anak disapih. Maka ternak betina akan kembali ke masa siklus birahi dan seterusnya. Letak kebuntingan pada ternak sapi biasanya pada daerah perut bagian kanan. Volume uterus mengembang mengikuti pertumbuhan embrio atau fetus yang dikandungnya. Sapi mengalami kebuntingan selama 9 bulan.

Breeding juga erat kaitannya dengan Inseminasi Buatan (IB). kesuksesan suatu program IB tergantung kualitas semen yang digunakan, ketepatan penempatan spermatozoa pada lokasi yang tepat di saluran reproduksi betina dan pada waktu yang tepat pula, sehingga spermatozoa yang berkualitas baik dapat bertemu dengan sel telur untuk terjadinya pembuahan (Inounu, 2014). Dalam pelaksanaan inseminasi buatan, bagi para pelaksana (inseminator) maupun pemilik sapi, sulit untuk mengetahui saat dimulainya estrus, lebih-lebih saat ovulasinya. Untuk memudahkan pelaksanaan, maka dibuat petunjuk umum yang dapat dipergunakan dengan mudah. Faktor terpenting dalam petunjuk tersebut adalah pengamatan terhadap birahi. Jika gejala birahi pada pagi ini, maka inseminasi harus dilakukan pada sore 
hari ini juga, jika sapi terlihat birahi pada sore hari ini maka inseminasi dilakukan esok harinya sebelum jam 12 siang.

Pemeriksaan kebuntingan pada sapi selain dapat untuk menentukan usia kebuntingan ternak sapi juga sekaligus dapat untuk menentukan diagnose perbedaan antara kebuntingan dengan kelainan atau gangguan pada organ reproduksi. Pemeriksaan kebuntingan dilakukan secara teratur dengan interval waktu antara 30-40 hari dari inseminasi yang terakhir. Sapi yang kemudian dinyatakan bunting, diperiksa kembali setelah 90-120 hari setelah pemeriksaan kebuntingan yang terakhir. Dengan demikian dapat untuk menghindari inseminasi ulang pada sapi yang sedang bunting.
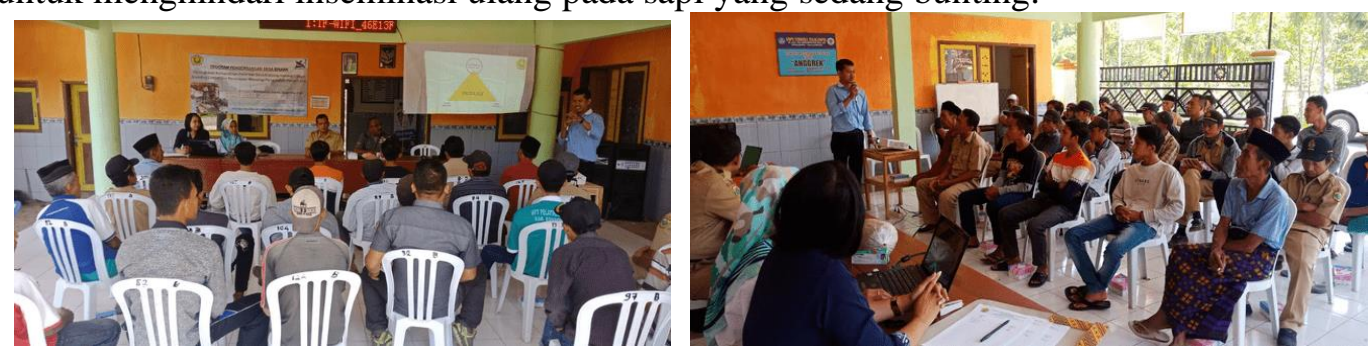

Gambar 7. Focus Group Discussion manajemen breeding

\section{Sosialisasi dan pelatihan pentingnya recording dan pengukuran body condition score bagi pembibitan ternak}

Kegiatan selanjutnya dalam program pengabdian desa binaan yaitu sosialisasi pentingnya recording atau pencatatan ternak dan pengukuran tubuh ternak atau body condition score. Recording ternak bertujuan untuk memudahkan pengenalan terhadap ternak, dengan mengetahui identitas dan ciri-ciri khusus ternak, serta mengetahui populasi ternak, memudahkan peternak mengingat kejadian-kejadian penting pada ternaknya, memudahkan peternak mengambil keputusan / tindakan dalam penanganan, perawatan dan pengobatan pada ternak yang sakit berdasarkan catatan riwayat kesehatannya dan memudahkan peternak melakukan seleksi ternak dan mencegah terjadinya inbreeding. Kegiatan recording meliputi identifikasi, pencatatan silsilah, pencatatan produksi dan reproduksi, pencatatan manajemen pemeliharaan dan kesehatan ternak.

Selain recording, pemeriksaan body conditioning score juga penting dalam pemilihan bibit ternak maupun pemilihan indukan. Body Condition Score (BCS), merupakan suatu metode untuk memberi skor kondisi tubuh ternak baik secara visual maupun dengan perabaan terhadap lemak tubuh pada bagian tertentu tubuh ternak. Tujuan penilaian BCS yaitu untuk mengetahui pencapaian standar kecukupan cadangan lemak tubuh yang akan mempengaruhi dalam penampilan produksi su su, efesiensi reproduksi dan herd longevity (Anisa et al., 2017). Waktu penilaian dapat dilakukan pada saat induk beranak (untuk menilai produksi kolostrum), setelah beranak (peningkatan produksi susu), saat dikawinkan (proses reproduksi), saat pemeriksaan kebuntingan (reproduksi dan laktasi), periode akhir laktasi (produksi susu) dan periode kering (saat bunting tua). Nilai BCS berkisar antara 1-5 (Sodiq dan Yuwono, 2017)

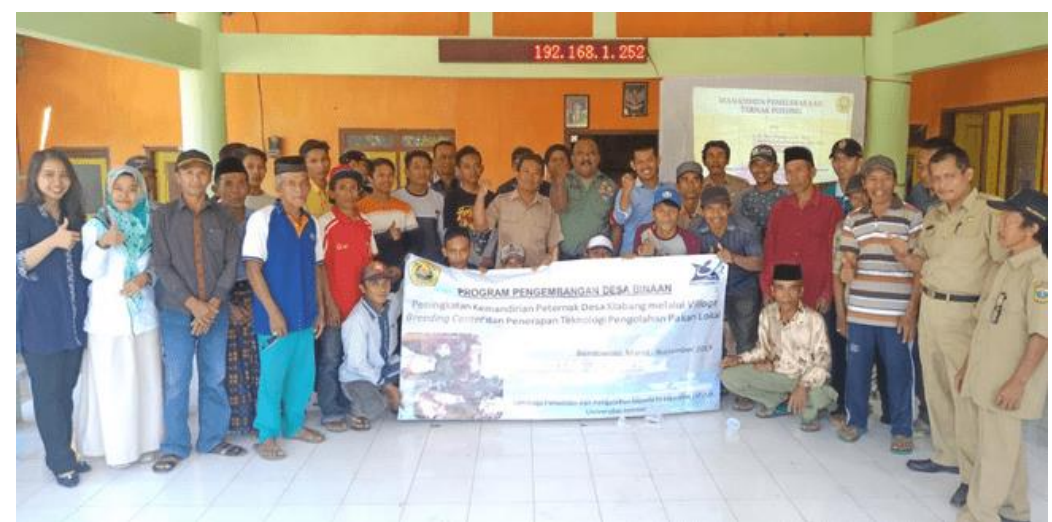

Gambar 8. Peserta sosialisasi dan pelatihan recording ternak dan pengukuran BCS. 


\section{Sosialisasi dan pelatihan pemanfaatan bahan baku lokal dan limbah pertanian yang masih mampu dimanfaatkan dengan baik sehingga meningkatkan nilai guna limbah}

Materi yang disampaikan dalam sosialisasi yaitu mengenalkan pakan ternak yang difermentasi untuk meningkatkan nutrisi pakan ternak dan meningkatkan ketersediaan pakan ketika kesulitan dalam mencari rumput. Pakan fermentasi yang disampaikan yaitu mengenai pembuatan silase, selain itu petani juga dikenalkan dengan pakan amoniasi, konsentrat fermentasi, dan mineral blok. Upaya perbaikan pakan dengan pemanfaatan bahan pakan lokal serta limbah tanaman pangan dan perkebunan yang mudah diakses peternak, telah membuka peluang bagi usaha pengembangan ternak tanpa bergantung pada pola ekstensif tradisional yang hanya mengandalkan padang penggembalaan alam (Wirdhayati, 2009)

Sosialisasi dilakukan dengan memberikan pengetahuan mengenai bahan-bahan pakan lokal yang dapat digunakan sebagai pakan ternak ruminansia (kambing, domba dan sapi) yang banyak terdapat di wilayah desa Klabang, Bondowoso. Beberapa bahan lokal tersebut merupakan limbahlimbah pertanian yang sangat melimpah dan belum dapat dimaksimalkan penggunaannya yaitu limbah tebon jagung, janggel jagung dan jerami padi. Petani dan peternak juga diberi pengetahuan dalam pemberian pakan yang baik dan benar sehingga menambah wawasan peternak untuk dapat mempraktekkan dengan harapan dapat meningkatkan poduktivitas ternak yang ada di wilayah tersebut. Teknik formuasi ransu komplit yang diberikan sangat sederhana, mudah dan murah untuk dipraktekkan. Peternak dan petani sangat antusias dalam mengikuti sosialisasi. Keterbatasan bahasa yang digunakan tidak menyurutkan semangat para petani dan peternak. Keterlibatan mahasiswa sebagai teknisi lapang dengan culture yang sama dengan para petani menjadikan komunikasi lebih lancar.

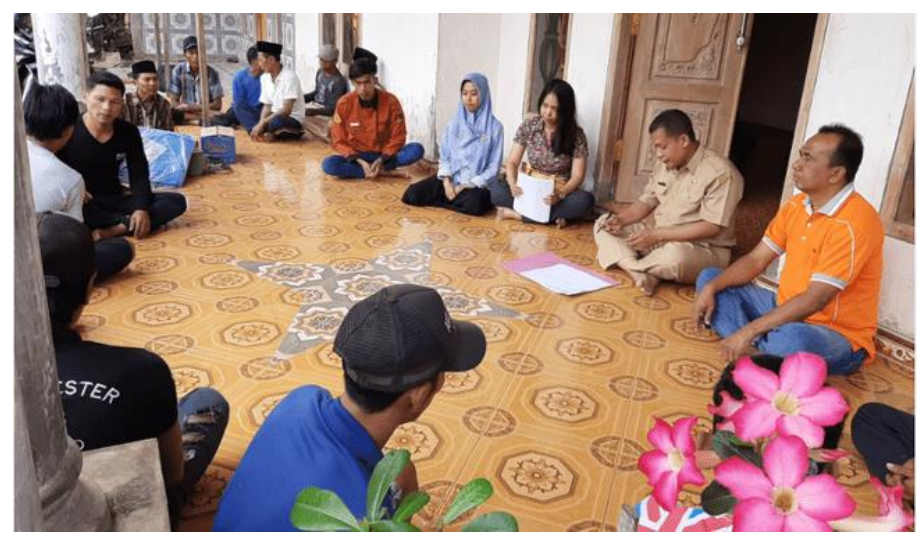

Gambar 9. Antusiasme peternak dalam menerima ilmu pengolahan pakan ternak

Pelatihan teknik fermentasi bahan baku lokal dan limbah pertanian untuk mengawetkan dan meningkatkan kualitas pakan ternak yaitu silase dan konsentrat fermentasi

Salah satu teknik pengolahan pakan hiajuan yang dapat diterapkan adalah fermentasi silase. Silase adalah pakan ternak yang diawetkan dalam wadah yang kedap udara atau drum dan sudah terjadi proses fermentasi dalam keaadaan anaerob. Proses silase ini melibatkan bakteri-bakteri atau mikroba yaitu, Lactis Acid dan streptococcus yang hidup secara anaerob dengan derajat keasaman $4(\mathrm{pH} 4)$ (Muck et al. 2018). Pelatihan dilakukan dengan tahapan memperkenalkan produk yang akan dibuat yaitu silase limbah pertanian dengan bahan baku utama jerami padi. Silase merupakan awetan hijauan dengan pemanfaatan mikroorganisme dengan proses fermentasi anaerob (Widyastuti, 2008). Tahapan proses pembuatan silase yaitu dengan pemotongan jerami padi dengan menggunakan parang, bisa pula dengan menggunakan mesin chopper yang akan dihibahkan dari dana program pengabdian desa binaan. Jerami padi yang telah tercacah kemudian ditambahkan dengan dedak padi, molases, garam dan probioter. Setelah tercampur, bahan pakan dimasukkan ke dalam kantong plastik bening dipadatkan hingga tidak 
terdapat rongga udara supaya proses fermentasi secara anaerob dapat optimal. Silase akan bisa dipanen setelah difermentasi selama 3-4 minggu. Silase juga dapat diberikan bahan aditif untuk meningkatkan kualitasnya seperti enzim selulosa, vitamin dan mineral yang dapat meningkatkan NDF (neutral detergent fiber) dan efisiensi pakan (Zahroiddin et al, 2004).

Petani/peternak desa Klabang sangat antusias dalam melakukan pelatihan pengolahan pakan fermentasi yaitu silase jerami padi untuk memenuhi kebutuhan pakan ternak mereka di musim kering. Harapan dalam pelatihan ini yaitu peternak mampu menyediakan pakan bernutrisi tinggi bagi ternaknya serta selalu tersedia kapan saja untuk mencukupi kebutuhan pokok ternak dalam berproduksi dan bereproduksi.

Adapun formulasi pakan yang bisa diadopsi dalam pembuatan baleage dapat dilihat pada tabel 3. dan tabel 4.

Tabel 1 Hasil analisis kandungan nutrien bahan hijauan silase (\% BK)

\begin{tabular}{lcrrrrr}
\hline \multicolumn{1}{c}{ Bahan pakan } & BK & Abu & $\begin{array}{c}\text { Protein } \\
\text { kasar }\end{array}$ & $\begin{array}{r}\text { Serat } \\
\text { kasar }\end{array}$ & \multicolumn{1}{c}{$\begin{array}{c}\text { Lemak } \\
\text { kasar }\end{array}$} & $\begin{array}{c}\text { Ekstrak tanpa } \\
\text { Nitrogen }\end{array}$ \\
\hline J. padi & 34,78 & 25,64 & 8,44 & 32,25 & 1,09 & 32,59 \\
J. jagung & 30,07 & 11,70 & 6,57 & 31,49 & 2,93 & 47,31 \\
Rumput raja & 15,67 & 14,60 & 8,17 & 30,77 & 5,45 & 41,01 \\
Gamal & 25,08 & 6,40 & 23,07 & 15,91 & 11,34 & 43,29 \\
J. kacang tanah & 18,01 & 9,71 & 13,75 & 26,01 & 3,80 & 46,73 \\
Molases & 77,44 & 7,90 & 3,84 & 0,39 & 0,30 & 87,57 \\
\hline
\end{tabular}

Sumber : Chalisty et al, 2017

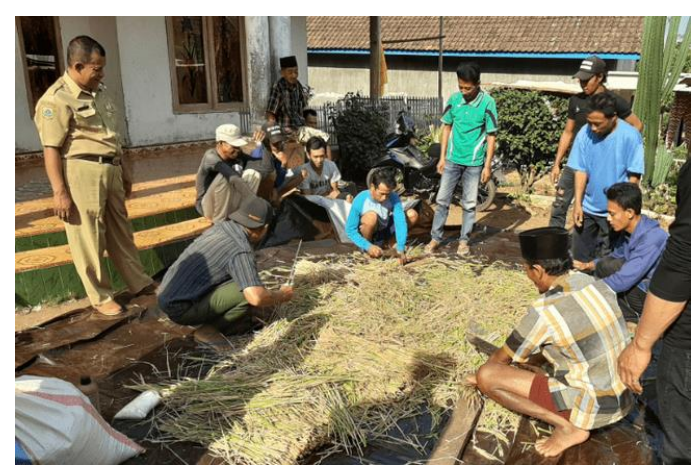

Gambar 10. Proses pencacahan jerami padi

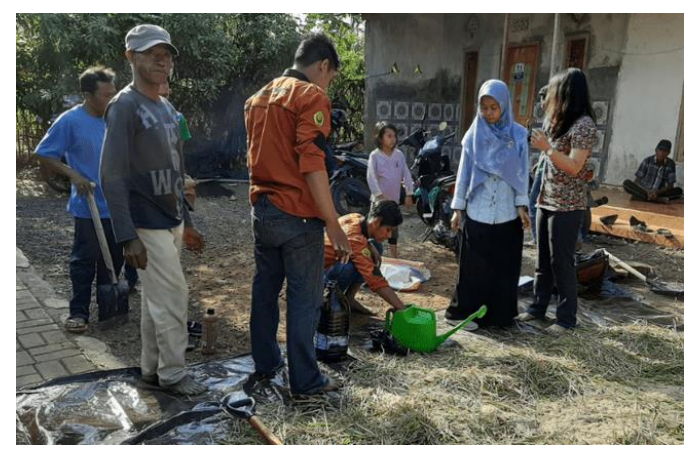

Gambar 11. Proses pencampran larutan molases garam dan probioter 


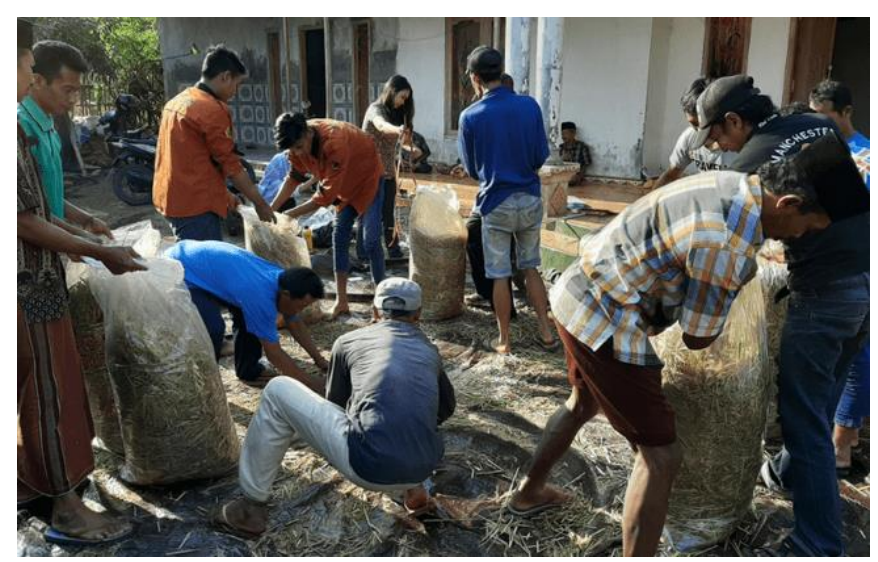

Gambar 12. Proses pengemasan anaerob silase jerami padi

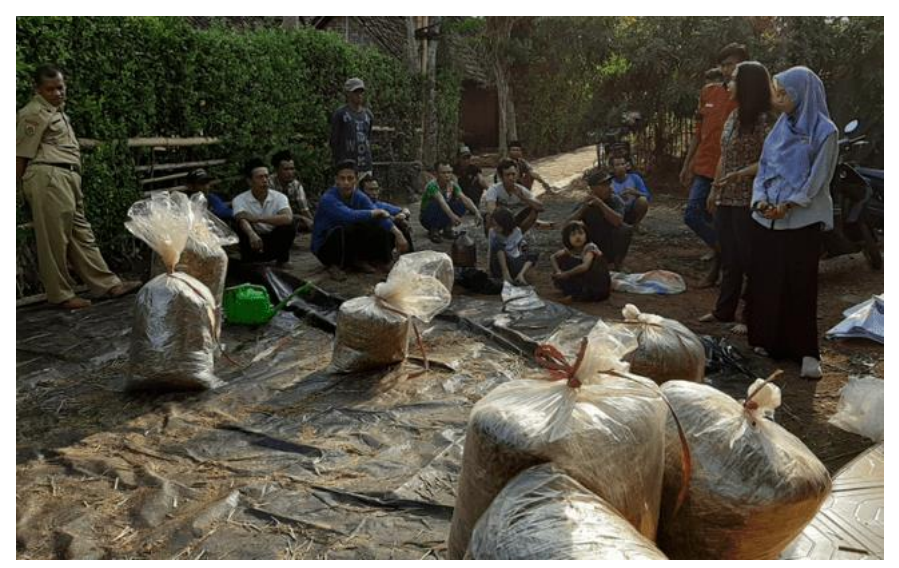

Gambar 13. Penjelasan mengenai teknik penyimpanan dan pencegahan kontaminasi

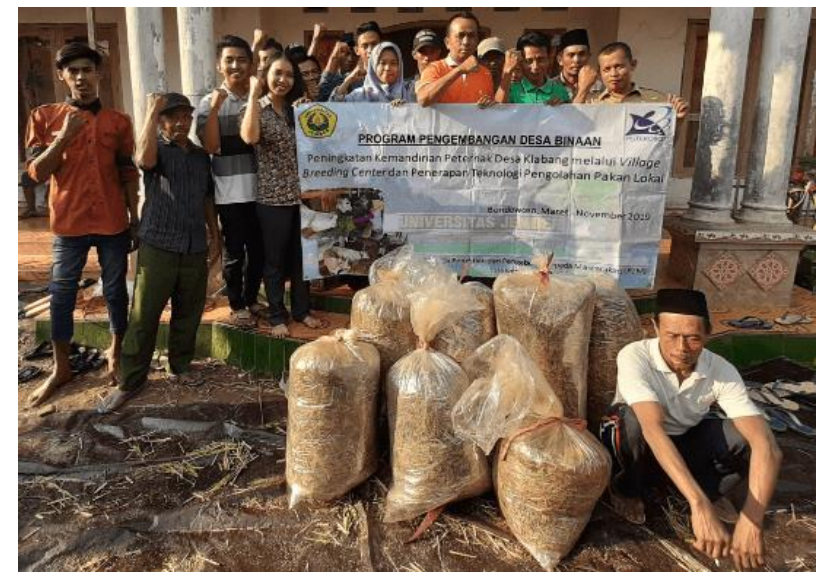

Gambar 14. Antusiasme peternak dalam pelatihan pengolahan pakan ternak asal limbah pertanian

\section{Monitoring dan evaluasi}

Kegiatan selanjutnya yang dilakukan yaitu monitoring hasil pengolahan silase jerami padi dan mencobakannya pada ternak untuk mengetahui tingkat daya suka ternak. Monitoring dilakukan dengan pengecekan hasil silase yang telah dibuat apakah memenuhi kriteria syarat silase yang baik atau tidak. Dalam silase akan terjadi beberapa tahap proses anaerob (proses tanpa udara/oksigen), dimana bakteri asam laktat akan mengkonsumsi zat gula yang terdapat pada bahan baku, sehingga terjadi proses fermentasi. 


\section{Kesimpulan dan Saran}

Berdasarkan hasil kegiatan program pengabdian desa binaan, petani dan peternak sangat antusias dalam mengikuti penyuluhan dan pelatihan. Peternak sudah mampu mengolah limbah pertanian berupa jerami padi menjadi pakan fermentasi berupa silase yang langsung dapat diberikan kepada peternak kambing, domba maupun sapi (ruminansia). Saran dari program pengabdian desa binaan ini yaitu perlu adanya kontinuitas dan komitmen dari para peternak desa klabang dalam mengolah limbah - limbah pertanian yang melimpah sehingga hasil olahan memiliki nutrien yang lebih tinggi dan memiliki daya simpan yang lebih panjang serta dapat dijual secara berkelanjutan pada peternak lain yang membutuhkan. Perlu juga pengorganisasian yang terstruktur seperti keterlibatan berbagai pihak seperti gabungan kelompok tani penyedia limbah, PPL, dan peternak yang mengoptimalkan limbah, karena kunci sukses pemanfaatan limbah yaitu kontinuitas penyedia, pembuat dan pengguna hasil olahan limbah yang dapat berupa silase dan konsentrat fermentasi.

\section{Ucapan Terimakasih}

Ucapan terima kasih disampaikan kepada LP2M Universitas Jember melalui hibah program pengabdian pemula yang telah memberikan pendanaan. Fakultas Pertanian Universitas Jember yang telah memberikan dukungan baik moral maupun material. Desa Klabang, Kecamatan Tegalampel, Kabupaten Bondowoso sebagai mitra dalam program ini.

\section{Daftar Pustaka}

Anisa E., Ondho Y.S. dan Samsudewa D. 2017. Pengaruh Body Condition Score(BCS) Berbeda terhadap Intensitas Birahi Sapi Induk Simmental Peranakan Ongole (SIMPO). Jurnal Sain Peternakan Indonesia Vol. 12 No. 2 : 133 - 141

Chalisty, V. D., R. Utomo., dan Z. Bachruddin, 2017. Pengaruh Penambahan Molases, Lactobacillus Plantarum, Trichoderma Viride, Dan Campurannya Terhadap Kualitas Silase Total Campuran Hijauan. 2017. Buletin Peternakan Vol. 41 (4): 431-438. DOI: 10.21059/buletinpeternak.v41i4.17337

Inounu, I. 2014. Upaya Meningkatkan Keberhasilan Inseminasi Buatan pada Ternak Ruminansia Kecil. WARTAZOA Vol. 24 No. 4: 201-209. DOI: http://dx.doi.org/10.14334/wartazoa.v24i4.1091

Khasanah, H., Purnamasari, L. and Kusbianto, D.E., 2020, January. Pemanfaatan MOL (Mikroorganisme Lokal) sebagai Substitusi Biostarter EM4 untuk Meningkatkan Kualitas Nutrisi Pakan Fermentasi Berbasis Tongkol dan Tumpi Jagung. In Prosiding Seminar Nasional Teknologi Peternakan dan Veteriner : 357-364.

Muck, R.E., Nadeau, E.M.G., McAllister, T.A., Contreras-Govea, F.E., Santos, M.C. and Kung Jr, L., 2018. Silage review: Recent advances and future uses of silage additives. Journal of dairy science, 101(5) : 3980-4000.

Sodiq, A dan Yumono, P., 2016. Pola Pengembangan dan Produktivitas Sapi Potong Program Kemitraan Bina Lingkungan di Kabupaten Banyumas dan Cilacap Propinsi Jawa Tengah. Agripet : Vol (16) No. $1: 56-61$

Widyastuti, Y. 2008. Fermentasi Silase dan Manfaat Probiotik Silase bagi Ruminansia. Media Peternakan, Vol. 31 No. 3, hlm. 225-232

Wirdahayati R.B. 2009. Penerapan Teknologi dalam Upaya Meningkatkan Produktivitas Sapi Potong di Nusa Tenggara Timur. WARTAZOA Vol. 20 No. 1: 12 - 20. 